\title{
Regional subsidence modelling in Murcia city (SE Spain) using 1-D vertical finite element analysis and 2-D interpolation of ground surface displacements
}

\author{
S. Tessitore ${ }^{1,2,3}$, J. A. Fernández-Merodo ${ }^{2,4,5}$, G. Herrera ${ }^{2,4,5}$, R. Tomás ${ }^{2,4,5,6}$, M. Ramondini ${ }^{3}$, \\ M. Sanabria ${ }^{2,4,5}$, J. Duro ${ }^{7}$, J. Mulas ${ }^{2,4,5}$, and D. Calcaterra ${ }^{1}$ \\ ${ }^{1}$ Department of Earth Sciences, Environment and Resources, Federico II University of Naples, Naples, Italy \\ ${ }^{2}$ Geohazards InSAR laboratory (InSARlab), Geoscience Research dept., Geological Survey of Spain (IGME), \\ C/. Alenza 1, 28003 Madrid, Spain \\ ${ }^{3}$ Department of Civil, Building and Environmental Engineering, Federico II University of Naples, Naples, Italy \\ ${ }^{4}$ Grupo español de trabajo en subsidencia del terreno (SUBTER) de la UNESCO \\ ${ }^{5}$ UNIRAD: Unidad Asociada de Interferometría Radar y Movimientos del Terreno de la Universidad de \\ Alicante y el Instituto Geológico y Minero de España, Spain \\ ${ }^{6}$ Departamento de Ingeniería Civil, Escuela Politécnica Superior, Universidad de Alicante, \\ P.O. Box 99, 03080 Alicante, Spain \\ ${ }^{7}$ Altamira Information, C/. Còrsega 381-387, 08037 Barcelona, Spain
}

Correspondence to: S. Tessitore (serena.tessitore@unina.it)

Published: 12 November 2015

\begin{abstract}
Subsidence is a hazard that may have natural or anthropogenic origin causing important economic losses. The area of Murcia city (SE Spain) has been affected by subsidence due to groundwater overexploitation since the year 1992. The main observed historical piezometric level declines occurred in the periods 1982-1984, 1992-1995 and 2004-2008 and showed a close correlation with the temporal evolution of ground displacements. Since 2008, the pressure recovery in the aquifer has led to an uplift of the ground surface that has been detected by the extensometers. In the present work an elastic hydro-mechanical finite element code has been used to compute the subsidence time series for 24 geotechnical boreholes, prescribing the measured groundwater table evolution. The achieved results have been compared with the displacements estimated through an advanced DInSAR technique and measured by the extensometers. These spatio-temporal comparisons have showed that, in spite of the limited geomechanical data available, the model has turned out to satisfactorily reproduce the subsidence phenomenon affecting Murcia City. The model will allow the prediction of future induced deformations and the consequences of any piezometric level variation in the study area.
\end{abstract}

\section{Introduction}

Subsidence due to ground water withdrawal could affect wide areas provoking severe damage to structures and infrastructures. More than 150 cities in the world are affected by this phenomenon (e.g. Venice, Bologna Ravenna, Mexico city, Santa Clara, San Joaquin Valleys, Antelope, Bangkok, Madrid, Guadalentín Valley, Almería, Granada and Sant Feliu de Llobregat, Orihulela city, Barcelona,... ) mainly due to an inefficient aquifer management. Among these, Murcia city (SE Spain) is located in the flood plain of the Segura River, (also known as the Vega Media of the Segura River, VMSR), whose aquifer was strongly exploited in the periods 1992-1995 and 2004-2008. This caused a moderate land subsidence in the whole VMSR which provoked damages to more than 150 buildings with an estimated cost of about EUR 50 million (Mulas et al., 2003). Consequently, the local authorities required detailed studies (e.g. Aragón et al., 2006; Herrera, et al., 2009; Mulas et al., 2003, 2010; Tomás, 2009) to understand the cause-effect mechanism of the phe- 
nomenon to improve the exploitation management. To this aim, an extensometric monitoring network was installed in 2001 and implemented in 2008 to cover the whole metropolitan area. Moreover, the land subsidence in Murcia City has been monitored by an innovative Differential SAR Interferometry (DInSAR) technique (Herrera, et al., 2009; Tomás, 2009). This technique allows measuring the ground surface displacements by calculating the differences between satellite SAR images acquired at different times and from different orbital positions. A-DInSAR techniques provide the displacement estimates, the velocity map and the displacements time series for the whole observation period along the satellite Line of Sight (LOS). These techniques have been effectively used to the subsidence monitoring as shown in many published works (Bru et al., 2013; Cascini et al., 2013; Ezquerro et al., 2014; Modoni et al., 2013; Sanabria et al., 2014; Tomás et al., 2014). Specifically, in the present work, the DInSAR processing of C-band SAR images achieved through the Stable Point Network (SPN) technique (Arnaud et al., 2003) for the period 1995-2008 (Terrafirma, 2008) has been used. In the present work, this information has been complemented with a subsidence finite element numerical model implemented by Tessitore et al. (2015), useful to analyse the cause-effect mechanism. This model allowed simulating the hydro-mechanical response of soils to water table variation. Specifically, the model was applied for the 24 columns where extensometric measurements are available (see their location in Fig. 1). Then, the 1-D subsidence results have been interpolated to obtain 2-D maps of deformation for the stable period (2001-2004), the drought period (2004-2008) and the recovery period (2008-2012). These maps have been compared with that achieved for the same periods through DInSAR and extensometric measurements.

\section{Description of the study area}

Murcia city (SE Spain) is located in the Vega Media of the Segura River Valley. The regional geological setting is characterized by the presence of a Permo-Triassic basement, mainly made up of limestones, dolomites and metamorphic rocks belonging to the Internal Zones of the Betic Cordillera. Three units represent the basin filling, ranging from Upper Miocene to Quaternary in age. The lowermost unit is given by Upper Miocene marls; the intermediate unit is constituted by a continental clastic succession with thick $250 \mathrm{~m}$ of marls and clays, intercalated with several levels of gravels and sands, dated from Pliocene-Quaternary to the present (Aragón et al., 2004). At its top recent sediments (mainly silts, clays and sands), with an overall thickness varying from 3 to $30 \mathrm{~m}$ (Rodríguez-Jurado et al., 2000) can be found. The geological settings generate a hydrogeological system constituted by (Aragón et al., 2004): (a) a deep aquifer which corresponds to a Pleistocene to Pliocene sequence of gravels and sands; (b) a surficial aquitard constituted by the first 5

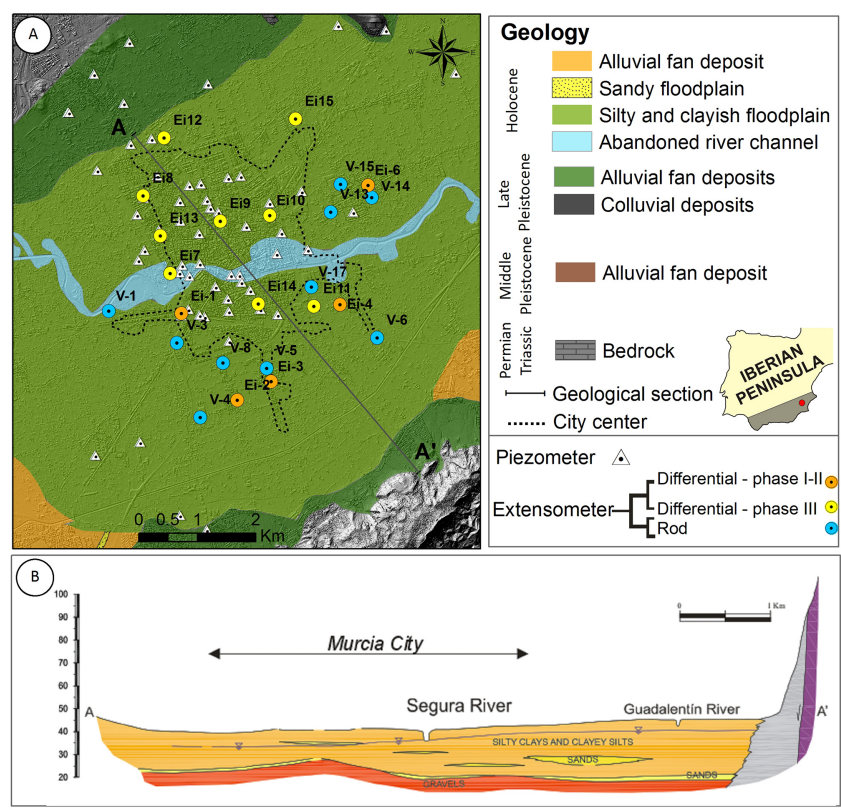

Figure 1. Geological Map (a), Geological cross section of the study area (b), (extracted from Mulas et al., 2003; modified after Tessitore et al., 2015).

to $30 \mathrm{~m}$ of recent clays, silts and sands (Fig. 1). The groundwater overexploitation interested the gravel layer located in the upper part of the deep aquifer. This provoked a water flow from the surficial aquitard to the gravel layer which triggered the consolidation of the surficial fine-grain soils. A geotechnical and hydrogeological characterization for the VMSR materials has been performed by Mulas et al. (2010) and used in the present work (Table 1). The parameters found in this study were obtained from hydrogeological tests, in situ (SPT, CPT-CPTU) and laboratory tests (triaxial tests, oedometric tests and uniaxial compressive strength tests) and stratigraphic records (ITGE and CPTOP, 2000).

\section{Monitoring data}

\subsection{Piezometers}

The piezometric network of the VMSR was installed in 1974, and extended during the years. Specifically, before 1994, only three piezometers were placed around the city of Murcia; in 1994, 46 new piezometers were drilled. In the following years $(1998,2000,2006,2008)$ the piezometric network reached the 111 units. Actually, 7 piezometers are currently available in the urban area of Murcia. The analysis of the measured groundwater table height shows three important piezometric level declines in the periods: 1982-1984, 19921995 and 2004-2008 respectively of 3.4, 8.3 and $12 \mathrm{~m}$. After the last drought period, a recovery period has been observed which has triggered to a ground surface uplift since the 2008 . 
Table 1. Summary of the geotechnical properties of the soils from the metropolitan area of Murcia city (from Mulas et al., 2010 and Tessitore et al., 2015). $\gamma_{\text {sat }}$ : specific saturated weight $\left[\mathrm{KN} \mathrm{m}^{-3}\right] ; k_{y}$ : vertical permeability $\left[\mathrm{ms}^{-1}\right] ; E$ : Young's modulus $\left[\mathrm{KNm}^{-2}\right] ; \nu$ : Poisson's coefficient.

\begin{tabular}{|c|c|c|c|c|c|c|c|c|c|c|c|c|}
\hline & \multicolumn{4}{|c|}{ City center } & \multicolumn{4}{|c|}{ Sector II } & \multicolumn{4}{|c|}{ Sector III } \\
\hline & $E$ & $\gamma_{\mathrm{sat}}$ & $k_{y}$ & $v$ & $E$ & $\gamma_{\mathrm{sat}}$ & $k_{y}$ & $v$ & $E$ & $\gamma_{\text {sat }}$ & $k_{y}$ & $v$ \\
\hline Clay & $\left(\mathrm{KN} \mathrm{m}^{-2}\right)$ & $\left(\mathrm{KN} \mathrm{m}^{-3}\right)$ & $\left(\mathrm{m} \mathrm{s}^{-1}\right)$ & & $\left(\mathrm{KN} \mathrm{m}^{-2}\right)$ & $\left(\mathrm{KN} \mathrm{m}^{-3}\right)$ & $\left(\mathrm{m} \mathrm{s}^{-1}\right)$ & & $\left(\mathrm{KN} \mathrm{m}^{-2}\right)$ & $\left(\mathrm{KN} \mathrm{m}^{-3}\right)$ & $\left(\mathrm{m} \mathrm{s}^{-1}\right)$ & \\
\hline Clay & 7500 & $20-20.3$ & $0.7-5.6 \times 10^{-10}$ & 0.35 & 10000 & 20 & $6.5 \times 10^{-9}$ & 0.35 & 13000 & 20 & $3.87 \times 10^{-9}$ & 0.35 \\
\hline Sand & $15000-20000$ & $20-20.8$ & $2.8-28 \times 10^{-9}$ & $0.3-0.35$ & $15000-20000$ & $20-20.8$ & $2.8-28 \times 10^{-9}$ & $0.3-0.35$ & $15000-20000$ & $20-20.8$ & $2.8-28 \times 10^{-9}$ & $0.3-0.35$ \\
\hline Gravel & 80000 & 21 & $2.8 \times 10^{-6}$ & 0.3 & 80000 & 21 & $2.8 \times 10^{-6}$ & 0.3 & 80000 & 21 & $2.8 \times 10^{-6}$ & 0.3 \\
\hline
\end{tabular}

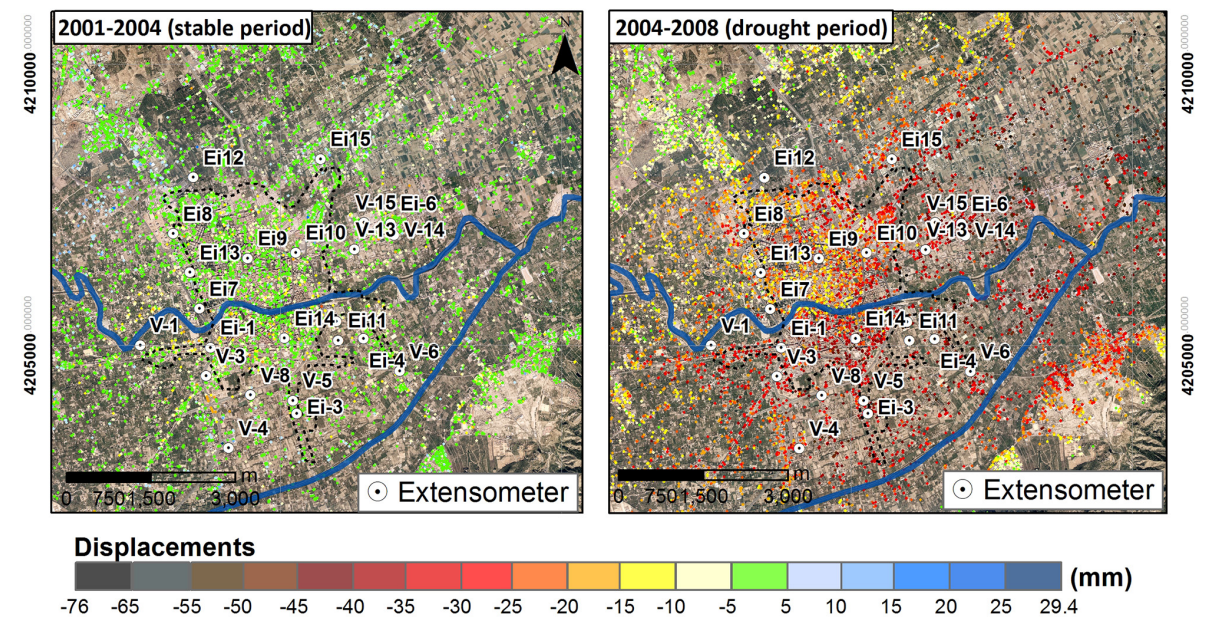

Figure 2. Cumulated DInSAR vertical displacement over two time periods: 2001-2004 (stable) and 2004-2008 (drought).

\subsection{Extensometers}

In Murcia city, a monitoring network of differential and rod extensometers was installed in February 2001 (phases 1 and 2) and extended in July 2008 (phase 3). In the first two phases 22 extensometers were drilled. In the 3 rd phase, 9 additional incremental extensometers were installed, including a piezometric sensor. However, only 17 extensometers (from the 31 installed) were operational in 2012. The extensometers measure the deformation of the firsts 10-20 $\mathrm{m}$ depth with accuracy of $0.1 \mathrm{~mm}$ for both the available types (Mulas et al., 2010).

\subsection{DInSAR data}

In the present work, 129 SAR images (ERS and ENVISAT) acquired from descending orbits between July 1995 and December 2008 were processed through the Stable Point Network (SPN) technique (Arnaud et al., 2003). Two different time periods were analyzed: 1995-2005 and 2004-2008 (Terrafirma, 2008). In particular, both datasets have been integrated in order to provide a continuous time series of the displacements along the period 2001-2008, which coincides with the period monitored by the extensometer network.
Figure 2 shows the spatial development of the subsidence of Murcia city. Specifically, taking into account the drought period, the cumulated displacements turned out to be more intense in the southern side of the river and in the eastern part of the city.

\section{Numerical model}

In Murcia city subsidence was provoked by the groundwater overexploitation which triggered the consolidation of compressible soils (Herrera et al., 2009; Tomás, 2009). The Biot's equation, which states a time dependent coupling behaviour between the solid matrix and the interstitial fluids of soils, has been solved using a Finite Element Model (FEM). In particular, the finite element code GeHoMadrid (FernandezMerodo, 2001; Mira, 2001), developed by the $\mathrm{M}_{2 i}$ group (Mathematical Models in Engineering) belonging to the Civil Engineering School of Madrid (Universidad Politécnica de Madrid) has been used.

In the present work, the 24 extensometric boreholes (see location in Fig. 1) have been modelled considering three main materials: gravel, sand and clay. Below the surficial gravel layer (where the pumping takes place) there are layers of consolidated hard clays and marls which have been considered as the incompressible and impervious bedrock for the displacement calculation. Therefore, only the deformations 

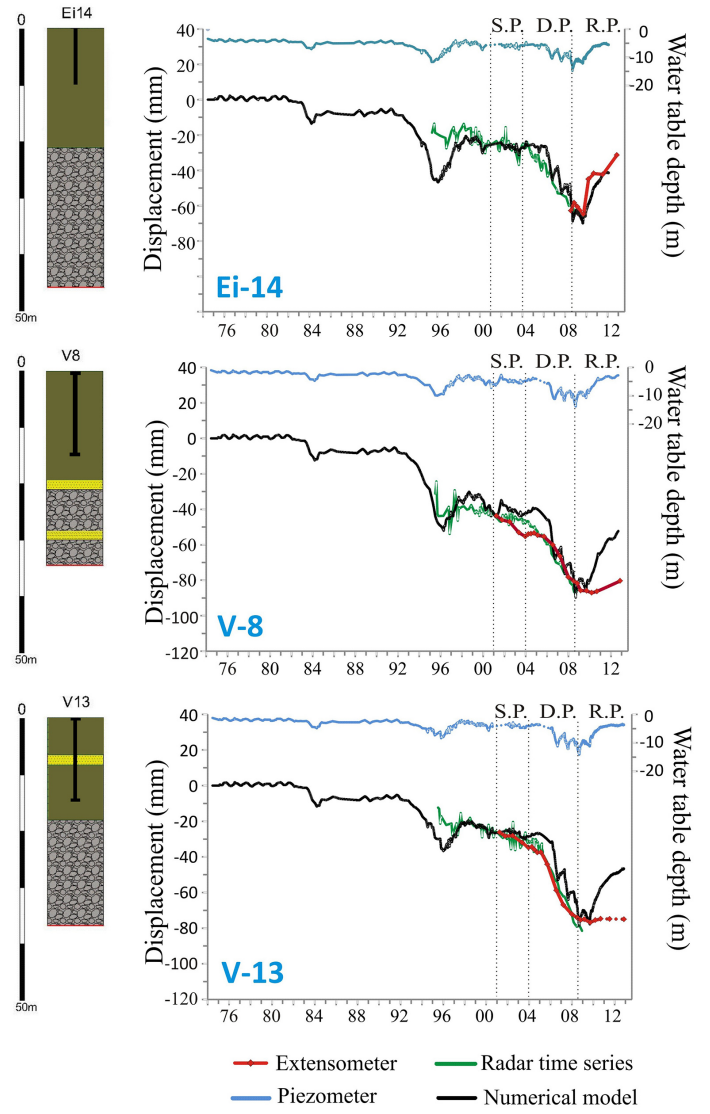

Figure 3. Modelled columns (clay: brown, sand: yellow, gravel: grey); computed and measured subsidence time series (extensometers and Radar); piezometric time series. (S.P.: stable period; D.P.: drought period; R.P.: recovery), redrawn after Tessitore et al. (2015).

occurred between the ground surface and the gravel layer bottom has been computed, considering an elastic behaviour for the materials and assuming a fully saturation condition (see Table 1).

For the boundary conditions, the gravel bottom has been fixed, the pore pressure variations have been prescribed on the base and no flux has been considered on the ground surface. Figure 3 shows some of the achieved results.

The 1-D model results have been interpolated to achieve the 2-D maps of deformations which have been compared with the ground-based and DInSAR-based ones (Fig. 4).

\section{Discussion and conclusions}

The comparisons between extensometric, radar data and numerical model results have allowed to analyse and justify the spatio-temporal differences among them. Specifically, the main differences found are referred to the drought period (2004-2008) where the extensometers registered a lower displacement than that measured through radar and the model

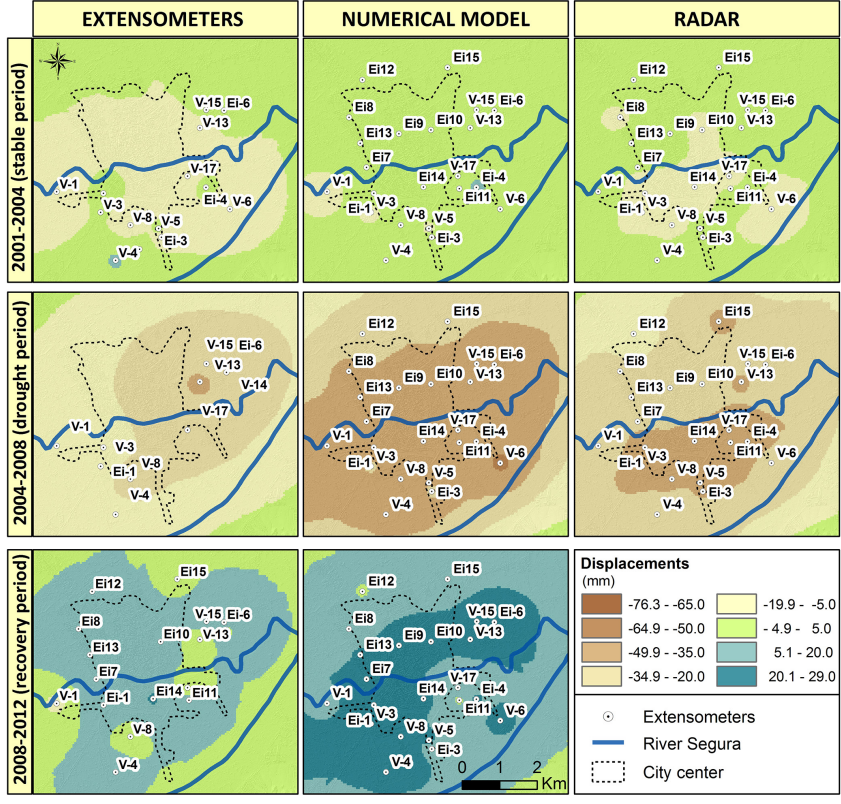

Figure 4. Spatial interpolation of the measured and computed displacements over the three considered periods: 2001-2004 (stable period), 2004-2008 (drought period), 2008-2012 (recovery period); redrawn after Tessitore et al. (2015).

ones. This can be due to the fact that the extensometer network is only measuring the deformations occurred in the firsts $10-20 \mathrm{~m}$ depth, while the radar measures the subsidence over the whole aquifer system. Concerning the recovery period, only the extensometers and the numerical model can be compared (Fig. 3). Columns V-8 and V-13 show that in some cases, the numerical model does not reproduce the measured deformation patterns. The numerical model predicts an uplift of the ground surface, due to the assumed elastic behaviour of the materials, whereas the extensometers exhibit no deformation, probably due to the fact that the measured displacement during the previous drought period (2004-2008) are plastic, producing irrecoverable deformation.

Thus, the implementation of a 1-D FEM model has permitted to effectively analyse the cause-effect mechanism of the subsidence phenomenon in Murcia city. In spite of the limited geotechnical and hydrogeological data available, the model has allowed to qualitatively and "quantitatively" reproduce the subsidence measured in Murcia city. Modelling is useful to the risk assessment because permit to predict the deformations induced by any piezometric level variation. This allows a better management of the ground water exploitation. 
Acknowledgements. This work has been supported by the Spanish Ministry of Economy and Competitiveness and EU FEDER funds under projects ESP2013-47780-C2-2-R and TEC201128201-C02-02 and by the project 15224/PI/10 from the Regional Agency of Science and Technology in Murcia. The European Space Agency (ESA) Terrafirma project funded all the SAR data processing with the SPN technique.

\section{References}

Aragón, R., Lambán, J., García-Aróstegui, J. L., Hornero, J., and Fernández-Grillo, A. I.: Efectos de la explotación intensiva de aguas subterráneas en la ciudad de Murcia (España) en épocas de sequía: orientaciones para una explotación sostenible, Boletín Geológico Y Minero, 117, 389-400, 2006.

Arnaud, A., Adam, N., Hanssen, R., Inglada, J., Duro, J., Closa, J., and Eineder, M.: ASAR ERS interferometric phase continuityGeoscience and Remote Sensing Symposium, 2003 IGARSS '03 Proceedings 2003 IEEE International, 1133-1135, vol.1132, 2003.

Bru, G., Herrera, G., Tomás, R., Duro, J., De la Vega, R., and Mulas, J.: Control of deformation of buildings affected by subsidence using persistent scatterer interferometry, Struct. Infrastruct. E., 9, 188-200, doi:10.1080/15732479.2010.519710, 2013.

Cascini, L., Peduto, D., Reale, D., Arena, L., Ferlisi, S., Verde, S., and Fornaro, G.: Detection and monitoring of facilities exposed to subsidence phenomena via past and current generation SAR sensors, J. Geophys. Eng., 10, 064001, doi:10.1088/17422132/10/6/064001, 2013.

Ezquerro, P., Herrera, G., Marchamalo, M., Tomás, R., BéjarPizarro, M., and Martínez, R.: A quasi-elastic aquifer deformational behavior: Madrid aquifer case study, J. Hydrol., 519, 1192-1204, doi:10.1016/j.jhydrol.2014.08.040, 2014.

Fernandez Merodo, J. A.: Une approche a la modelisation des glissements et des effondrements de terrains: Initiation et propagation (Thesis), Ecole Centrale Paris, 2001.

Herrera, G., Fernández, J. A., Tomás, R., Cooksley, G., and Mulas, J.: Advanced interpretation of subsidence in Murcia (SE Spain) using A-DInSAR data - modelling and validation, Nat. Hazards Earth Syst. Sci., 9, 647-661, doi:10.5194/nhess-9-6472009, 2009.
ITGE \& CPTOP: Estudio Geotécnico para el análisis prevención y correción de la patología derivada de los cambios en el subsuelo de la Ciudad de Murcia, Informe inédito, 208 pp., 2000.

Mira, P.: Analisis por elementos finitos de problemas de rotura de geomateriales (Thesis), Universidad Politecnica de Madrid, ETSICCP, Madrid (Spain), 2001.

Modoni, G., Darini, G., Spacagna, R. L., Saroli, M., Russo, G., and Croce, P.: Spatial analysis of land subsidence induced by groundwater withdrawal, Eng. Geol., 167, 59-71, doi:10.1016/j.enggeo.2013.10.014, 2013.

Mulas, J., Aragón, R., and Clemente, A. A.: La subsidencia del terreno en la ciudad y área metropolitana de Murcia: Modelización, seguimiento y control (coord. Madrid: Instituto Geológico y Minero de España y Consejería de Obras Públicas y Ordenación del Territorio de la Comunidad Autónoma de la Región de Murcia), 2010.

Mulas, J., Aragón, R., Martínez, M., Lambán, J., García-Aróstegui, J. L., Fernández-Grillo, A. I., Hornero, J., Rodríguez, J., and Rodríguez, J. M.: Geotechnical and hydrogeological analysis of land subsidence in Murcia (Spain), Materials and Geoenvironment, 50, 249-252, 2003.

Sanabria, M. P., Guardiola-Albert, C., Tomás, R., Herrera, G., Prieto, A., Sánchez, H., and Tessitore, S.: Subsidence activity maps derived from DInSAR data: Orihuela case study, Nat. Hazards Earth Syst. Sci., 14, 1341-1360, doi:10.5194/nhess-14-13412014, 2014.

Tessitore, S., Fernández-Merodo, J. A., Herrera, G., Tomás, R., Ramondini, M., Sanabria, M., Duro, J., Mulas, J., and Calcaterra, D.: Comparison of water-level, extensometric, DInSAR and simulation data for quantification of subsidence in Murcia City (SE Spain), Hydrogeol. J., (HJ-2015-3677), submitted, 2015.

Tomás, R., Romero, R., Mulas, J., Marturià, J. J., Mallorquí, J. J., Lopez-Sanchez, J. M., Herrera, G., Gutiérrez, F., González, P. J., Fernández, J., Duque, S., Concha-Dimas, A., Cocksley, G., Castañeda, C., Carrasco, D., and Blanco, P.: Radar interferometry techniques for the study of ground subsidence phenomena: a review of practical issues through cases in Spain, Environmental Earth Sciences, 71, 163-181, doi:10.1007/s12665-013-2422z, 2014.

Tomás, R.: Estudio de la subsidencia de la ciudad de Murcia Mediante Interferometría SAR diferencial avanzada, Universidad de Alicante, 2009. 